\title{
UN RELATO DE TRASLACIÓN DE RELIQUIAS EN LA CASTILLA DEL SIGLO XV: LA OBRA DE ALONSO DE CARTAGENA*
}

\author{
POR \\ LUIS FERNÁNDEZ GALLARDO ${ }^{1}$ \\ UNED de Albacete-SEMYR
}

\section{RESUMEN}

El relato de traslación de reliquias es un género de literatura religiosa que no tuvo amplio desarrollo en la Castilla medieval. Pero Alonso de Cartagena contribuyó a éste notablemente. En 1453, durante una visita pastoral, decidió trasladar las reliquias de santa Juliana a un lugar más honorable. Compuso un relato de los hechos que se ajusta con rigor a los rasgos del género. Escrito en castellano, contiene una exposición sobre la conveniencia del culto a los santos y sus reliquias de intensa inspiración tomista, que expone con rigor y claridad cuestiones teológicas. Las disposiciones sobre la decoración de la capilla de las reliquias ofrecen por su posición equidistante un interesante testimonio del debate sobre la imagen religiosa que se desarrollaba entonces en Castilla.

PALABRAS CLAVE: Reliquias; culto de santos; literatura religiosa; Castilla; siglo XV; Alonso de Cartagena.

\section{AN ACCOUNT OF TRANSLATION OF RELICS: THE WRITINGS OF ALONSO DE CARTAGENA}

\begin{abstract}
The narratives of translation of relics is a genre of devotional literature that didn't develop extensively in Medieval Castile. But Alonso de Cartagena contributed to it remarkably. In 1453, during a pastoral visit, he decided to move the relics of St. Juliana to a more honorable place. He wrote an account of these facts that adjusts strictly to the features of the genre. This vernacular text contains an exposition about the cult of saints and their relics, which has an intense Thomist inspiration: it sets theological questions with precision and clarity. The provisions on the decoration of the chapel of the relics offer an interesting testimony of the debate on religious image which is then developed in Castile.
\end{abstract}

KEY WORDS: Relics; Cult of saints; Devotional literature; Castile; 15th Century; Alonso de Cartagena.

COMO CITAR ESTE ARTículo / CITATION: Fernández Gallardo, L. 2017. «Un relato de traslación de reliquias en la Castilla del siglo XV: la obra de Alonso de Cartagena». Hispania Sacra 69,140: 521-531. doi: 10.3989/hs.2017.032

Recibido/Received 04-06-2015

Aceptado/Accepted 10-06-2015
El relato de la traslación de reliquias constituye un género litúrgico-narrativo bien definido dentro de la literatura devota², asociado a una de las facetas más

\footnotetext{
* Este trabajo forma parte del Proyecto de Investigación Alonso de Cartagena. Obras Completas, FFI2014-55902-P, Ministerio de Economía y Competitividad, que dirige el Prof. Juan Miguel Valero Moreno (Universidad de Salamanca-SEMYR).

1 Ifernandez@albacete.uned.es / ORCID iD: http://orcid.org/0000 -0002-5012-9166

2 Estudiado con rigor por Heinzelmann 1979. Sobre el acto litúrgico propiamente dicho, aunque referido al ámbito germánico, ofrece valiosa información Kühne 2000: 520-533.
}

características de la religiosidad del Medievo, el culto de las reliquias. ${ }^{3}$ En él convergen el torrente de fe popular que tiende a desbordar los cauces que establece la Iglesia y la acción normativa de ésta, que se extiende tanto a la fundamentación teológica de esta práctica piadosa como a su regulación legal. Sumamente significativo a este respecto es el hecho de que la segunda compilación de decretales, la que promovió Bonifacio VIII (1298), incluyó un apartado específico referido a las reliquias y a la

\footnotetext{
3 Son de especial interés las síntesis de Angenendt 1994: 149-189
} y 2010 . 
veneración de los santos, que se mantendrá en los libros posteriores del Corpus luris Canonici. ${ }^{4}$ Las circunstancias específicas por las que atravesó la península ibérica en el Medievo determinaron la remoción de numerosas reliquias. Los avatares de las reliquias custodiadas en el Arca Santa de la catedral de Oviedo son paradigmáticos al respecto: en la dramática confusión de la invasión islámica, fueron trasladadas de Toledo a Asturias. EI prelado ovetense Pelayo (†1153) compuso el relato de sus accidentadas peripecias. ${ }^{5}$

$Y$ sin embargo, el género narrativo del traslado de reliquias no tuvo un desarrollo relevante en España, donde sus manifestaciones más destacadas asumieron una dimensión nacional y, por tanto, política, por asociarse al culto de santos a los que se atribuía un papel tutelar, protector de la España cristiana. Es el caso de la traslación más notable de época medieval, tanto por la calidad de las reliquias removidas como por la trascendencia del acto litúrgico: la de san Isidoro, cuyos restos fueron llevados a León en 1063 y depositados en el monasterio de San Isidoro, que el rey Fernando I de Castilla erigió en panteón real. El relato de dicha traslación, compuesto en 1064, se incorporó a la Historia Silense, ${ }^{6}$ evidenciando de este modo su dimensión política. Habrá que esperar a fines del siglo XIII o comienzos del XIV para poder reseñar otro relato de traslación destacado: el de las reliquias de san Ildefonso, debido al franciscano Juan Gil de Zamora (ca. 1241-ca. 1318). ${ }^{7}$

Por todo ello, adquiere especial importancia la contribución a este género del célebre obispo de Burgos Alonso de Cartagena (1385-1456), una de las figuras más relevantes del panorama político y cultural del reinado de Juan II de Castilla. Dentro de la amplia y variada producción literaria de Alonso de Cartagena (1385-1456), el escrito sobre el traslado de las reliquias de santa Juliana ocupa un lugar en cierto modo marginal: no figura siquiera en la meritoria y rigurosa relación de los testimonios textuales de su obra vernácula. ${ }^{8}$ Ciertamente, su naturaleza de documento que da fe de los actos de dicha traslación podía justificar que se prescindiera de él en la consideración de la producción propiamente literaria del prelado burgalés. De hecho, la primera biografía de don Alonso, que contiene un detallado catálogo de su obra literaria, no hace mención a este texto, en tanto que se refiere a los actos solemnes de la traslación. ${ }^{9}$ Y sin embargo, esta obra constituye un testimonio cabal de dicho género litúrgico-narrativo.

\footnotetext{
4 Liber Sextus 3.22; Clementinae 3.16; Extravagantes Communes 3.12 .

Historia de Arcae Sanctae translatione, ápud Flórez 1789: 352 357. Asimismo se compuso otro relato a fines del siglo XII o comienzos del XIII, contenido en sendos manuscritos, francés e inglés, respectivamente, que realza los elementos legendarios (Kohler 1897).

6 Acta translationis corporis S. Isidori, ápud Lorenzana 1862: cols. 40-43 > Historia Silense: 198-204.

7 Fita 1885.

8 Morrás 2003. No escapó, en cambio, a la diligente mirada del P. Serrano, quien en su biografía del prelado burgalés llamó la atención sobre la pastoral que precede al relato de la traslación, indicando someramente sus contenidos (Serrano 1942: 219-220). Partiendo de tales indicaciones, incluyó Morrás sólo parte del texto completo de la traslación, el sermón, en su muy completa bibliografía sobre Cartagena (Morrás 1991: 230).
}

9 De actibus Alfonsi de Cartagena, ápud Lawrance 2000: 150.

\section{I.- GÉNESIS DEL TEXTO}

Esta obra surge en el desarrollo de la actividad pastoral del prelado burgalés, circunstancia de la que él mismo dejó constancia en el propio texto. ${ }^{10}$ En efecto, en 1453 llevó a cabo don Alonso una visita pastoral, recorriendo la parte norte de su diócesis. En Santillana estuvo de enero a marzo, resolviendo diversos asuntos. Se alojó en la casa del capiscol Diego Gómez de Santillana. ${ }^{11}$ En enero pronunció sentencia en el pleito suscitado por las quejas de los beneficiados de la colegiata de Santillana acerca de los apremios de los visitadores de la sede burgalesa, que les exigían, a pesar de las exenciones que aquéllos alegaban, «Procuración, nin Vesitacion, nin Cathedratico, nin Susidio, nin otro cualquier derecho». ${ }^{12}$ Ya en este documento, surgido en el marco de la potestad jurisdiccional del prelado, se manifiesta el interés de don Alonso por la iglesia y reliquias de santa Juliana, interés acrecentado por el hecho de que casi habían caído en el olvido dichas reliquias. Ni siquiera se sabía dónde yacían. En la Traslación se apelaría a la «communis opinio» como garante de que la iglesia de Santillana poseía el cuerpo de la santa que le daba nombre. ${ }^{13}$ De ahí que el obispo burgalés se afanara en la búsqueda del cuerpo de la santa, que finalmente fue hallado, junto con otras reliquias.

Así, pues, ya antes del veintiocho de enero habían sido localizadas las de santa Juliana y se había decidido trasladarlas a un lugar más decoroso. A partir de ahí comienzan las gestiones para el traslado: tratarlo con los beneficiados de la iglesia colegial, con los vecinos más preeminentes de la villa, notificarlo al titular del señorío, el Marqués de Santillana, que había de dar su consentimiento. Tales gestiones se extendieron a lo largo del mes de febrero, acordándose finalmente que los actos de la traslación tuvieran lugar ya en el mes de marzo. ${ }^{14}$

De regreso a Burgos, don Alonso comunicó todos estos extremos al deán y cabildo de la catedral, quienes habían de dar su consentimiento en lo relativo al cambio de la festividad de santa Juliana, que pasó a celebrarse el día de la traslación de sus reliquias. Dicho consentimiento quedó formalizado en un documento, que da testimonio de la reunión del obispo con su cabildo, celebrada en la capilla de santa Catalina, a la sazón sala capitular, el 16 de septiembre de $1453 .{ }^{15}$ Dicha carta incorporó el texto de la traslación, por lo que constituye su testimonio más antiguo.

\section{II.- ESTRUCTURA Y RASGOS GÉNERICOS}

El documento en cuestión se confeccionó para hacer públicas las decisiones acordadas por el obispo y su

10 «Lo qual considerando Nos el dicho Don Alfonso Obispo de Burgos, quando en este año presente [ $=1453]$ andovimos por diversas partes de nuestro Obispado..." (Alonso de Cartagena, Traslación de las reliquias de Santa Juliana [= Traslación], ápud Escagedo Salmón 1927: 375. Existe asimismo una copia manuscrita del siglo XVIII, elaborada para el P. Flórez, que no figura en la citada bibliografía de Morrás (Biblioteca Nacional de España [= BNE], ms. 9550, ff. 513 ro-520 vo).

11 Como informa la sentencia pronunciada a favor del cabildo de Santillana (Escagedo Salmón 1927: 366).

12 Sentencia pronunciada por don Alonso de Cartagena el 28 de enero de 1453 (ibídem: 365).

13 Traslación: 375-376.

14 Traslación: 376-377.

15 Ibídem: 380. 
cabildo, que regulan el culto y devoción de las reliquias de santa Juliana. Como preámbulo y justificación de tales disposiciones se incluyó la Traslación, obra en la que cabe distinguir dos partes claramente diferenciadas dentro del continuum textual, que se refieren a diferentes momentos del proceso de traslación de las reliquias.

En primer lugar, un sermón sobre la licitud del culto de las reliquias. ${ }^{16}$ Se desarrolla una reflexión teológica que deriva en una suerte de historia de la moral desde una perspectiva trascendente, que va a constituir el marco en que se sitúa el culto de las reliquias. Así, los medios de que dispone el hombre para alcanzar el mayor bien, la visión y fruición de Dios, constituyen dones divinos: razón natural, Decálogo, Redención, predicación apostólica, ejemplo de mártires. Se ha considerado el sermo como forma antigua y autónoma de la traslación de reliquias; podía incluir disquisiciones teológicas, ${ }^{17}$ como en el caso de la obra de Cartagena.

Tras la sección homilética figura el relato propiamente dicho de la traslación: localización de las reliquias, decisión de su traslado a lugar más decoroso y eminente, gestiones necesarias y ceremonias de traslado. ${ }^{18}$ Sin solución de continuidad le siguen las disposiciones de carácter litúrgico que estableció el obispo burgalés: la invocación de santa Juliana tras la de la Virgen María. ${ }^{19}$ La cláusula absoluta que marca la transición a la siguiente sección del documento ${ }^{20}$ viene a representar el cierre del texto de la Traslación, al determinar inequívocamente la serie completa de los actos ceremoniales y litúrgicos que constituyen el objeto de la narración.

Rasgo formal característico de los relatos de traslación es el uso de la primera persona del plural, con que se indica la participación del autor en los hechos referidos. ${ }^{21}$ En la obra de Cartagena, dicha forma pronominal no sólo indica su participación en los hechos referidos, sino que constituye un plural mayestático con el que se expresa el ejercicio de la potestad episcopal.

La estructura que presenta la Traslación responde, pues, a las pautas propias de un género bien definido, que se había configurado a lo largo de una larga tradición, en la que la parte narrativa constituía el núcleo esencial. ${ }^{22}$ Cartagena se ajustaba al molde formal adecuado a los contenidos que se proponía transmitir, poniendo así de manifiesto una decidida voluntad de forma en la articulación del discurso. El hecho de que presente un desarrollo más amplio el sermón introductorio, con la meditada reflexión teológica que se despliega para avalar la práctica piadosa del culto a las reliquias, es revelador de la índole reflexiva de su genio intelectual, que se proyecta asimismo sobre su religiosidad.

16 Ibídem: 368-375.

17 Heinzelmann 1979: 54-55.

18 Traslación: 375-377. En cierto modo, se ajusta tal secuencia al esquema considerado por Heinzelmann 1979: 56-57 (origen, traslación y llegada de las reliquias al lugar determinado).

19 Traslación: 377.

20 «E esto assi fecho...» (ibídem: 376-377).

21 Heinzelmann 1979: 53-54.

22 «Der eigentliche «Prototyp» der Translationsberichte [...] besteht aus einer selbständigen Erzählung, zu der ein Prolog und selbst ein Epilog treten kann». (Ibídem: 53). Del cultivo de este género en España ofrece una indicación a través de los supuestos testimonios perdidos Deyermond 1990: 144-145.

\section{III.- UN SERMÓN}

Calificada de pastoral por el P. Serrano ${ }^{23}$, el sermón introductorio constituye efectivamente una carta dirigida por el prelado a sus diocesanos ${ }^{24}$, para mostrarles el verdadero sentido y finalidad del culto de las reliquias de santa Juliana, cuyo descubrimiento y traslado había promovido. Don Alonso obvia la consideración de las virtudes de la santa, adoptando una perspectiva más abstracta: el significado religioso del culto a los santos y sus reliquias en general. Frente al carácter concreto, local asociado al culto a las reliquias, el obispo de Burgos optaba por genéricas consideraciones sobre la índole piadosa de dicho culto. No se extenderá en el recuerdo del martirio de la santa como testimonio de fe. Así, pues, no la devoción a la santa, sino la devoción en general es lo que constituye el objeto de los desvelos pastorales del prelado burgalés.

\section{1.- Una reflexión teológica: beatitud y progreso moral del hombre}

El punto de partida de las reflexiones de don Alonso es el amor de Dios al hombre, creado a su imagen y semejanza. Este amor es el que lo mueve a proveerle de aquellos medios que le permitan alcanzar «el mayor bien, e don que pensarse pueda» (Traslación: 368-369). En primer lugar, se determina cuál es ese mayor bien: «la Bienaventurança perdurable». ${ }^{25}$ En este punto, Cartagena procede a una distinción más propia de la disquisición teológica que de la homilía pastoral. Dicha bienaventuranza perdurable en tanto que objeto se identifica con Dios, pero, en tanto que acción del hombre para su consecución, se corresponde con la visión y fruición de Dios. A través de la prosa vernácula se transparenta el rigor de la reflexión teológica. Visión y fruición son conceptos netamente delimitados por la ciencia teológica.

El primer término es un cultismo utilizado desde los primeros monumentos literarios castellanos, especialmente por autores del mester de clerecía. ${ }^{26}$ En el contexto de la Traslación remite a la doctrina tomista de la visión beatífica, con la que se identifica la felicidad del hombre, el «mayor bien $»{ }^{27}$ El segundo es asimismo un cultismo, entonces de reciente incorporación al castellano, sobre la base de los testimonios reunidos en el Corpus del Nuevo Diccionario Histórico del Español. Se documenta por primera vez en Enrique de Villena. ${ }^{28}$ La doctrina tomista de la fruición, con su distinción entre el objeto o fin de ella y su obtención es

\footnotetext{
23 Serrano 1942: 219

24 Así consta en la salutación: «... á todas, é qualesquier personas Eclesiasticas é seglares de la tierra de Asturias de Santillana, é todas las otras tierras é logares de nuestro Obispado salud e bendicion». (Traslación: 368).

25 Traslación: 369.

26 Bustos Tovar 1974: 727-728 y, sobre todo, Nuevo Diccionario Histórico del Español [= NDHE], s.v. visión <http://web.frl.es/CNDHE/ view/inicioExterno.view>

27 «... ultima et perfecta beatitudo non potest esse nisi in visione divinae essentiae». (Santo Tomás de Aquino, Summa Theologiae, I-II, q. 3, a. 8).

$28 N D H E$, s.v. fruición.
} 
perceptible en la terminología utilizada. ${ }^{29}$ De este modo, el sermón introductorio adquiere una densidad doctrinal, un rigor teológico más propio del texto concebido para la lectura individual que para ser pronunciado ante los fieles reunidos en la iglesia de Santillana.

A la consecución de ese bien supremo se subordinan los diferentes medios que permiten «guiar la vida temporal en este mundo movible e lleno de alteraciones, é mudanças, por que mereciesen reçebir este don» (Traslación, p. 369). En primer lugar, la razón natural y el entendimiento, concebidos como dones otorgados por Dios para que el hombre pudiese conocer lo honesto para seguirlo y lo deshonesto para evitarlo. La razón natural referida al orden moral se corresponde con la ley natural. $Y$ en este punto se advierte de nuevo la inspiración tomista de los argumentos desarrollados, procedentes de la exposición del Aquinate acerca de la ley natural ${ }^{30}$, que se enmarca en una concepción que atribuye a la ley una función pedagógica en la vida moral. ${ }^{31}$

La caída del hombre en el pecado hasta el extremo de provocar la ira divina y decidir el exterminio del género humano a excepción de Noé ponía de manifiesto la insuficiencia de la razón y el entendimiento para conocer y seguir adecuadamente el bien..$^{32}$ Fiel a la letra de la Escritura, don Alonso, urgido por su insobornable rigor intelectual, ha de hacer una precisión: a pesar de que ésta refiera que Dios se arrepintió de haber creado al hombre ${ }^{33}$, alega que en Dios no cabe arrepentimiento. Aunque la observación venga dictada por principios teológicos (en la perfección divina no cabía el error o corrección del curso providencial), se acoge a un locus bíblico para demostrar que en Dios no es posible el arrepentimiento. Y sin embargo, acepta como indiscutible la letra del relato bíblico sobre el Diluvio. ${ }^{34}$

En este punto el optimismo racional de Cartagena llegaba al límite establecido por la fe cristiana: la razón natural es sólo un medio que ayuda a discernir el bien del mal, pero no garantiza la salvación, que procede de la gracia. Por ello, Dios otorgó el Decálogo, de manera que la

29 «E por que el mayor bien, e don que pensarse puede era é es la Bienventurança perdurable, que es él mesmo, considerándole como á objeto della é la Visión, é fruicion del, considerandola respectivamente á la action del Ome que aquella bienaventurança alcançase...» (Tras/ación: 368-369). Cfr.: «Ad tertium dicendum quod, sicut supra dictum est finis dicitur dupliciter, uno modo, ipsa res; alio modo, adeptio rei. Quae quidem non sunt duo fines, sed unus finis, in se consideratus, et alteri applicatus. Deus igitur est ultimus finis sicut res quae ultimo quaeritur, fruitio autem sicut adeptio huius ultimi finis». (Santo Tomás de Aquino, Summa Theologiae, I-II, q. 11, a. 3).

30 "Quia vero bonum habet rationem finis, malum autem rationem contrarii, inde est quod omnia illa ad quae homo habet naturalem inclinationem, ratio naturaliter apprehendit ut bona, et per consequens ut opere prosequenda, et contraria eorum ut mala et vitanda». (Santo Tomás de Aquino, Summa Theologiae, I-II, q. 94, a. 2).

31 Álvarez Turienzo 1987: 428.

32 «E considerando su infinida Sabiduria que por la lumbre de la raçon natural los omes non conoscian perfectamente lo que debían facer...» (Traslación: 369-370).

33 Cfr. Genesis, 6, 5-7.

34 «E aunque en Dios non cae arrepentimiento cá dice un Propheta en otro logar: El vencedor en Isrrael non se arrepentirá, nin se abaxará, ó mudará con arrepentimiento». (Traslación: 369). Cfr. «Porro triumphator in Israel non parcet, et poenitudine non flectetur...» (1 Samuelis, 15, 29). Es de notar el modo de traducir el texto bíblico de Cartagena, que apunta más al sentido que al apego a la estricta literalidad. ley natural era complementada por la Ley, incluida en las Sagradas Escrituras, aunque se condensan en el Decálogo, la ley escrita en las tablas de Moisés. ${ }^{35}$ Es evidente el esfuerzo de don Alonso por limitar este nuevo don divino a los "mandamientos" veterotestamentales, ya que, aun cuando se refiere a la «Sancta Scriptura» como depositaria de dichos mandamientos, centra su atención en el Decálogo. De nuevo se advierte la inspiración tomista de estas consideraciones: la relación de complementariedad entre ambos tipos de ley, natural y escrita, había sido establecida por Santo Tomás de Aquino en su exposición sobre los diferentes tipos de leyes. ${ }^{36}$

Pero los mandamientos divinos tampoco resultaban suficientes para que "el Ome anduviese por las vías derechas» (Traslación, p. 371), de ahí que Dios tuviera que otorgar un nuevo don para enderezar su rumbo hacia el bien: la Encarnación del Verbo Divino. Don Alonso centra su atención no tanto en el misterio de la Redención, cuanto en la dimensión pedagógica del mensaje de Cristo. Así, tras referirse a la Encarnación y a la Redención, expone el papel de Cristo en la provisión de los medios necesarios para que el hombre actuara en este mundo de manera que pudiera alcanzar lo que él mismo denomina «bienaventuranza perdurable». ${ }^{37}$

Al menos en este punto, la concepción cristológica de Cartagena realza la dimensión humana de Jesús, en la medida en que focaliza su acción benéfica sobre el hombre en su actividad en el mundo. Mas no hay que perder de vista el contexto en que figuran tales consideraciones, situadas tras la rigurosa enunciación de los misterios de la Encarnación y Redención, ni, sobre todo, la fórmula introductoria («mas aun en tanto que en esta vida andovo») $)^{38}$, que viene a indicar cierto carácter complementario a dichas consideraciones. Ahora bien, precisamente el contexto le otorga pleno sentido, pues la enseñanza de Cristo procedería no de una sabiduría humana, sino de su condición de hijo de Dios. ${ }^{39}$ Precisamente la exposición, desarrollada con rigor teológico en lengua vernácula, sobre la Encarnación, determina la autoridad divina de sus enseñanzas.

Diríase que la profunda vocación pedagógica de Alonso de Cartagena se proyecta en su concepción de la acción

35 «Por ende la divina piedad, allende la raçon natural, que al Ome dio, quisole dar mandamientos saludables, según que latamente parescen por la Santa Scriptura, assi aquellos diez principales que se llaman Decalogo, como otros muchos que están dispersos por Sacro Canon. Los quales todos aunque son muchos en numero, se pueden reduçir, é reduçen á los diez principales». (Traslación: 370).

36 «Ad primum ergo dicendum quod lex scripta dicitur esse data ad correctionem legis naturae, vel quia per legem scriptam suppletum est quod legi naturae deerat, vel quia lex naturae in aliquorum cordibus, quantum ad aliqua, corrupta erat intantum ut existimarent esse bona quae naturaliter sunt mala; et talis corruptio correctione indigebat». (Santo Tomás de Aquino, Summa Theologiae, I-II, q. 94, a. 5).

37 San Agustín expuso claramente dicha dimensión pedagógica de la venida de Cristo: "Tota itaque vita ejus [= Cristo] in terris, per hominem quem suscipere dignatus est, disciplina morum fuit». (S. Agustín de Hipona 1865, col. 135).

38 Traslación: 371.

39 Tal y como ha planteado Ratzinger 2007: 29: "La doctrina de Jesús no procede de enseñanzas humanas, sean del tipo que sean, sino del contacto inmediato con el Padre, del diálogo "cara a cara" ». Precisamente las consideraciones precedentes sobre el misterio de la Encarnación salvaguardaban la naturaleza divina de Cristo, de que dimanaba su enseñanza. Es de notar que la cristología tomista reducía la humanidad de Cristo a algo pasivo y accidental (Harnack 1890: 452). 
de Jesús en este mundo, centrada en la enseñanza, cuyo enunciado se demora en una serie de términos que delimitan con precisión el alcance de la actividad del Salvador. ${ }^{40}$ Así, la difusión del mensaje redentor de Cristo es presentado como educación moral del hombre. Palabras y obras, predicación y acción: se destaca la complementariedad de los medios utilizados en esa formación moral que llevó a cabo a Jesús. Para ello se acoge a la autoridad de las Escrituras, a lo "scripto», sin referirse a ningún locus concreto. ${ }^{41}$

Si bien pareciera que el proceso de otorgamiento de dones para el reconocimiento del bien culminaba y adquiría plenitud con las enseñanzas de Cristo, éstas se prolongan en las «doctrinas» y "actos» de los "Sanctos Apostolos». ${ }^{42} \mathrm{Se}$ rompe ciertamente la estructura del progreso en la sucesión de los dones divinos para la perfección moral del hombre, pero la enseñanza de los apóstoles venían a constituir el nexo que permitía insertar el culto a los mártires dentro de ese proceso de progresiva revelación de medios para que el hombre guíe sus pasos rectamente en este mundo.

En primer lugar, la insistencia en la complementariedad de la enseñanza de doctrinas y actos establece el marco adecuado en el que se sitúa el testimonio martirial. La formulación presenta un acusado sesgo escriturario en el sentido en que remite a los libros neotestamentarios como testimonio de la acción apostólica: las cartas de los apóstoles y los Hechos de los apóstoles. ${ }^{43}$ La condición de mártires de los apóstoles constituye el nexo con aquellos santos y santas -la inclusión de mujeres apuntaba directamente a santa Juliana- que dieron igualmente testimonio de la fe católica con su muerte. ${ }^{44}$

Alonso de Cartagena revela una vez más la índole pedagógica de su genio intelectual. Sin omitir los aspectos morbosos de la muerte martirial, predomina, empero, la dimensión educativa de su testimonio. Así, la retórica de la truculencia apenas es utilizada: ciertamente era inevitable la referencia al sufrimiento martirial, pero el obispo de Burgos evita el detalle escalofriante, la complacencia en la descripción de la crueldad ejercida sobre los santos. Es más, el espanto y sobrecogimiento que causa la contemplación del tormento se torna belleza, una belleza espiritual ciertamente, que ilumina los tonos sombríos de las imágenes del martirio. Una cita veterotestamental viene a corroborar esta visión luminosa de la muerte martirial, presentada como ejemplo de «quan preciosa es la Sancta

40 «... en tanto que en esta vida andovo dio muchos preceptos, mandamientos, é consejos, é dotrinas, é exiemplos saludables, obrandolos el é enseñando como los obrasen los otros». (Traslación: 371).

41 "Cá scripto es, que començo á facer é enseñar...» (ibídem: 371). Los testimonios neotestamentarios más cercanos al texto de la Traslación son Evangelium secundum Matthaeum, 4, 23 («Et circuibat lesus totam Galilaeam, docens in sinagoga eorum, et praedicans evangelium regni: et sanans omnem languorem, et omnem infirmitatem in populo».) y, sobre todo, Actus Apostolorum, 1, 1 («Primum quidem sermonem feci de omnibus, o Theophile, quae coepit lesus facere, et docere...»)

42 Traslación: 371.

43 «... quiso que los Sanctos Apostolos suyos diesen, é enseñasen muchas, é notables doctrinas, según por sus Epistolas, é actos parescen». (Ibídem: 371-372).

44 «E ellos [= apóstoles], é otros muchos Sanctos é Sanctas, que ovo en la Eglesia primitiva enseñaron por palabra é mostraron por exiemplo, quan preciosa es la Sancta Fé Catholica, rescibiendo muchos tormentos, é muertes muy crueles por la confession della». (Ibídem: 372).
Fé Catholica». ${ }^{45} \mathrm{Y}$ es que el adjetivo "precioso» aparece de modo recurrente a lo largo de la exposición sobre la enseñanza de los mártires ${ }^{46}$, extendiendo su connotación a las consideraciones sobre la muerte martirial.

Muy significativamente el carácter secundario que presenta la evocación del sufrimiento de los mártires se pone de manifiesto en la misma elocución, figurando en cláusula subordinada a aquella otra que refiere la predicación que llevaron a cabo estos mismos mártires. ${ }^{47}$ De este modo, don Alonso se distanciaba de las formas de piedad características del Bajo Medievo, en las que el dolor y la mortificación de la carne constituían vías de imitación de Cristo, del Cristo sufriente representado con crudo realismo en la pintura gótica. En su lugar, se destaca la acción pedagógica llevada a cabo por los mártires.

Alonso de Cartagena, urgido por la necesidad de proporcionar el marco adecuado a la justificación del culto de las reliquias, ofrecía, así un cuadro evolutivo de los principios morales que han de guiar al hombre en el mundo en su camino hacia la salvación, algo así como una historia de la educación moral, que se presenta como una sucesión de dones divinos que arrancan de la razón natural y llegan hasta el ejemplo de apóstoles y mártires. Si cabe asimilar tales enseñanzas con la ley que prescribe el comportamiento humano orientado a su recto fin, se advierte la inspiración tomista de tal planteamiento, en la medida en que Santo Tomás consideraba la ley como el instrumento del que se vale Dios, principio exterior que mueve al hombre hacia el bien, para instruirlo. ${ }^{48}$ La aportación de Cartagena consistiría en conferirle una acusada dimensión pedagógica a la doctrina tomista sobre la ley. Y llegados a este punto, extraña el que el docto prelado burgalés no diga nada de los méritos de la santa cuyas reliquias motivaban sus desvelos pastorales. La figura de santa Juliana queda reducida a una simple opinión común que afirmaba que sus restos mortales reposaban en la iglesia de Santillana. Ni una palabra acerca de las razones y circunstancias de su martirio, del que el texto canónico, la Leyenda áurea, ofrecía un relato que detallaba la hiperbólica sevicia de los verdugos de la santa ${ }^{49}$ : diríase que Cartagena elude los pormenores morbosos del martirologio.

\section{2.- Sobre las reliquias}

Una vez situada la significación de santos y mártires dentro de ese plan providencial de sucesivos otorgamientos de principios morales al hombre para que guíe sus pasos hacia la salvación, se enlaza con la cuestión de la veneración de sus cuerpos, de las reliquias. Una vez más, don Alonso encuentra en la doctrina del Aquinate los argumentos idóneos para

45 Ibídem: 374. Cfr.: «Pretiosa in conspectu Domini/ Mors sanctorum eius». (Psalmi, 115, 15). Cartagena traduce el texto bíblico de este modo: "Cá scripto es: Preciosa es en el acatamiento del Señor la muerte de sus Sanctos». (Traslación: 374).

46 Cuatro veces para calificar a la fe católica, al sacrificio y, en dos ocasiones, a la propia muerte de los mártires (ibídem: 372).

47 Cfr.: «E en las mesmas pasiones, é recepción de las plagas, é açotes, é cruas feridas predicaban a los tyranos, é á aquellos que les atormentaban doctrinas sanas de la verdad Catholica...» (ibídem: 372).

48 Santo Tomás de Aquino, Summa Theologiae, I-II, q. 90.

49 Jacobus a Voragine 1890: 177-178. 
justificar el culto de las reliquias. Diríase que esta parte del sermón constituye una reelaboración del análisis de Santo Tomás acerca de la licitud de esta práctica devota. ${ }^{50}$

Lo que en el Aquinate no dejaba der ser una referencia secundaria deviene punto de partida de las consideraciones de Cartagena: los cuerpos de los santos que han de ser venerados están llamados a resucitar..$^{51}$ El destino final de dichos cuerpos sería la «gloria eternal»: ésta venía a ser para el obispo de Burgos la razón fundamental que justificaba su veneración. Al argumento teológico se añade la ilustración etimológica, que introduce nuevas consideraciones. En efecto, no sólo se incluye el étimo, conforme al Catholicon de Johannes Januensis, esa enorme cantera de material léxico que tanto frecuentara don Alonso, sino las consideraciones que añade el docto lexicógrafo dominico. Así, la finalidad del culto a las reliquias que figura tras la noticia etimológica viene una a ser una demorada amplificatio de las escuetas razones del Catholicon: se veneran las reliquias para recordar las almas de los santos y para mover a su imitación..$^{52}$

Como si sintiera insuficiente el fundamento teológico expuesto tras la explicación del étimo, don Alonso añade a las razones del Catholicon, nuevos argumentos, a la vez que rebate a quienes impugnaron la licitud de esta práctica devota. La veneración de las reliquias en última instancia se subordinaba a la que era debida al Creador. Los términos se han escogido cuidadosamente para dejar claras las jerarquías en el culto cristiano: reverencia y honor para las reliquias, adoración para Dios, de quien dimana el mérito que les es reconocido a ellas..$^{53}$ De este modo, con impecable rigor conceptual, que mantiene en la prosa vernácula, quedaba cubierto el flanco a la crítica del culto de las reliquias como culto de latría. La adoración se reservaba para Dios, con lo que quedaba limitado el alcance de la honra concedida a las reliquias.

Cartagena incluye seguidamente la aclaración de la exacta naturaleza del culto de las reliquias, que viene a refutar las razones contrarias. De acuerdo con la doctrina de Santo Tomás, deslinda con precisión la adoración de latría y la veneración de las reliquias. La primera sólo se debe a Dios. ${ }^{54}$ Ahora bien, las reliquias no se veneran por

50 Santo Tomás de Aquino, Summa Theologiae, III, q. 25, a. 6.

51 "Quiso la inefable sapiencia divinal que los cuerpos en que aquellas benditas animas estovieron, en quien han de tornar á se unir en la universal resurrección, é quedar unidos por siempre en la gloria eternal, fuesen ávidos en este mundo en gran veneración...» (Traslación 372-373). Cfr.: «Et ideo eorum reliquias qualescumque honore congruo in eorum memoriam venerari debemus, et praecipue eorum corpora, quae fuerunt templum spiritus sancti, et organa spiritus sancti in eis habitantis et operantis, et sunt corpori Christi configuranda per gloriam resurrectionis». (Santo Tomás de Aquino, Summa Theologiae, III, q. 25, a. 6).

52 «... los cuerpos [...] que comunmente llamamos reliquias por que fueron assi relinquidas, e dexadas de los Sanctos, se miembren de aquel tiempo en que las Sanctas animas en ellos eran, é de la Vida, é actos loables, que facian, é miembrandose trabajen por seguir quanto su flaqueza podiere, las justas é piadosas, é loables vías...» (Traslación: 373). Cfr.: «Reliquie, a relinquo [...] Item relique dicuntur ossa et vestimenta sanctorum, que nobis relinquuntur, ut eorum merita recolentes eos digne ueneremur et eorumuitam imitemur». (Johannes Balbus 1460: f. 301 ro-voo, s. v. reliquie.

53 «Et faciendo reverencia, é onor á las Sanctas reliquias, é adorando a Dios todo poderoso, que tanta gracia dio á aquellos cuyas ellas son...» (Traslación: 373).

54 «Ca mucho erraron aquellos que cuidaron que los Catholicos adoran las reliquias, é Cuerpos de los Sanctos por adoracion de latria, sí mismas, sino en cuanto que medio para la adoración del Creador. Don Alonso reproduce el argumento con que Santo Tomás refutaba las objeciones a la licitud de esta práctica devota, basado en la autoridad de san Jerónimo, que impugnara las tesis de Vigilancio contrarias al culto de las reliquias. Reproduce, mediante traducción literal del texto latino, la cita que hace el Aquinate de san Jerónimo. ${ }^{55}$ Ahora bien, en la prosa vernácula, en aras de una mayor eficacia didáctica, se hace más explícita la subordinación de la veneración de las reliquias a la que se debe al Creador, eludiendo la terminología propia de la ciencia teológica. Así, el concepto de causa, esgrimido por Santo Tomás para establecer el vínculo entre los santos y Dios, se torna mera equivalencia entre la adoración rendida a las reliquias y al Creador. ${ }^{56}$

Cartagena debía de sentir que éste era el argumento clave para la justificación del culto de las reliquias, pues completa la argumentación de Santo Tomás con una cita bíblica que viene a remachar la idea de que en última instancia la veneración de las reliquias tiene por objeto a Dios. Para introducirla, se vale de la condición de siervos del Señor que atribuye a los santos ${ }^{57}$, que no era sino una variación de la de ministri, que les adjudicara Santo Tomás.

Las consideraciones anteriores convergen en la afirmación, a modo de conclusión, de la índole piadosa y meritoria del culto de las reliquias de los santos ${ }^{58}$, de lo cual se deriva la necesidad de conservarlas en lugares honorables. Don Alonso no pierde nunca de vista que las reliquias no son un fin, sino un medio para la adoración del Creador. Por ello, deja bien claro que el decoro y la honorabilidad de los lugares donde reposan las reliquias se subordinan al estímulo de la oración, a acendrar la devoción con que ésta se ha de hacer. ${ }^{59}$ Esta idea constituye el nexo que enlaza con la cuestión del traslado de reliquias. En efecto, una vez declarada la genuina finalidad de su localización decorosa, la búsqueda de un lugar más honorable se justificaba en función de la correspondiente devoción a que moverían las reliquias trasladadas.

que es de plena, é entera servidumbre por que aquella solamente es debida á Dios, é non a Criatura alguna...» (ibídem: 373).

55 Traslación: 373-374 < Santo Tomás de Aquino, Summa Theologiae, III, q. 25, a. 6. El mismo Aquinate había establecido una diferencia entre dos formas de veneración: la que se debe a Dios (latria) y la que se practica con criaturas excelentes en virtud de cierta participación con Dios (dulía) (Summa Theologiae, II-II, q. 84, a. 1). Y sin embargo, desde presupuestos filológicos, Lorenzo Valla demostraría lo artificioso de dicha distinción, afirmando la equivalencia de ambos términos: «... ut appareat inter ipsa uerba latriam et duliam nihil interesse...» (Valla 1526: 17).

56 «... pero honramos las reliquias de los Sanctos Martyres, por que adoramos aquel cuyos Martyres son...» (Traslación: 374). Cfr.: "Ad secundum dicendum quod corpus insensibile non adoramus propter seipsum, sed [...] propter Deum, cuius fuerunt ministri». (Santo Tomás de Aquino, Summa Theologiae, III, q. 25, a. 6).

57 «... é honramos á los Siervos por que el honor dellos retorne en el Señor, el qual dixo á sus Apostoles: Quien á vos rescibe, á mi rescibe...» (Traslación: 374). Cfr.: «Qui recipit vos, me recipit...» (Evangelium secundum Matthaeum, 10, 40).

58 «Por ende cosa piadosa, é meritoria es honrar, é facer referencia á los Cuerpos, é reliquias de los Sanctos Martyres, é [...] Sanctos...» (Traslación: 374). Y es que las reliquias poseían una virtualidad sacramental (Angenendt 1994: 157). Otras facetas del culto a los santos y sus reliquias ofrece Brown 1981: 86-105.

59 Traslación: 375. 
Y de la justificación del traslado de reliquias se pasaba al relato del que impulsó Alonso de Cartagena. ${ }^{60} \mathrm{El}$ sermón adquiere entonces pleno significado como homilía sobre la verdadera naturaleza del culto de las reliquias. El docto prelado se esforzaba por inculcar a la feligresía de Santillana que la veneración de las reliquias tiene como genuina finalidad la adoración del Creador, que constituyen un medio para despertar una mayor devoción.

\section{IV.- EL RELATO DE LA TRASLACIÓN}

La exposición sobre la licitud del culto de las reliquias servía de preámbulo y justificación de las decisiones que adoptó Alonso de Cartagena, en el ejercicio de sus atribuciones como obispo, con relación a las de santa Juliana, que reposaban en la colegiata de Santillana. De la reflexión teológica se pasa a la narración de las actuaciones promovidas por el prelado burgalés. El relato comprende todo el proceso desde el hallazgo de las reliquias hasta las ceremonias de su traslado, ajustándose a la estructura interna tradicional, que consta de tres partes: origen de las reliquias, traslado al lugar de culto donde se venerarán y llegada al lugar determinado para su depósito. ${ }^{61}$

La particularidad que esta traslación ofrece reside en el hecho de que tiene lugar dentro de la misma iglesia, esto es, constituye más propiamente una recolocación de las reliquias en el interior del mismo templo que una traslación. Aun así, se observa un desarrollo ceremonial ajustado a los esquemas tradicionales.

\section{1.- Hallazgo de las reliquias}

Don Alonso inicia el relato de la Traslación con la referencia a las circunstancias personales en que se produjo: en 1453 se hallaba realizando una visita pastoral en diversos lugares de su diócesis. ${ }^{62}$ Es de notar que el rastro documental de la actividad pastoral es muy tenue: por análoga referencia personal deslizada en su Duodenarium cabe localizar otra visita de esta naturaleza hacia 1442. El hecho de que en edad tan provecta se decidiera a recorrer la diócesis revela gran celo en el cometido de sus obligaciones como obispo. ${ }^{63}$ En el curso de la visita una de las cuestiones que debía de preocuparle era el estado de los lugares de culto y devoción. Estando en Santillana del Mar observó el mal estado en que se encontraban las preciadas

60 Mediante la fórmula de transición siguiente: «Lo qual considerando Nos el dicho Don Alfonso Obispo de Burgos...» (Traslación: 375).

61 Heinzelmann 1979: 56-57.

62 «... Nos el dicho Don Alfonso Obispo de Burgos, quando en este año presente andovimos por diversas partes de nuestro Obispado, siguiendo en ello [...] exiemplo de nuestro glorioso Redemptor...» (Traslación: 375).

63 Cuya ejemplaridad destacara Fernando de Pulgar en su galería de varones ilustres de Castilla: «Puesto en esta dignidad guardó tan bien los precebtos que, segund los sacros cánones y decretos debe guardar el perlado, que fue enxenplo de vida y dotrina a todos los otros perlados que fueron en su tienpo». (Pulgar 1985: 141). Tal vez el empeño que puso en que los beneficiados de su diócesis residieran en el lugar de sus beneficios le moviera a realizar tales visitas. Acerca de esta preocupación véase Fernández Gallardo 2002: 264-265. reliquias de santa Juliana. Es de notar la prudente cautela que adopta al referirse a dichas reliquias: «según Comun opinion era sepelido, é recóndito el Sancto Cuerpo, é reliquias de Bienaventurada Virgen é Martir Sancta Juliana». Es de notar que don Alonso distingue en este contexto con nitidez, a diferencia del que daba cuenta de la etimología del término, entre los restos corporales y los objetos que habían tenido relación con la santa, para los que reserva el término reliquia, como si retomara la distinción que hacía la iglesia oriental entre cuerpo y objetos de los santos. ${ }^{64} \mathrm{En}$ cuanto al "santo cuerpo", parece colegirse que Cartagena entendía que estaba entero, esto es, que no se trataba de partes del mismo, aun cuando el hecho de que ya en el siglo VIII se documente el traslado de una mártir Juliana a Cumas, siendo de allí transferida a Nápoles en $1207^{65}$, abone la suposición de que podría tratarse de fragmentos.

No se trataba, pues, de un hallazgo propiamente dicho, ya que las reliquias se veneraban en la colegiata de Santillana y atraían a romeros y peregrinos. ${ }^{66}$ Diríase, pues que las circunstancias son más bien prosaicas, alejadas del habitual despliegue de hechos sobrenaturales, especialmente la visión que revela la voluntad del santo ${ }^{67}$, con que se realzaba la calidad de las reliquias.

Especial interés presenta el modo como don Alonso se refiere a la presencia de las reliquias en la colegiata. Como corresponde a su probidad intelectual $-y$, sobre todo, a sus hábitos de erudito jurista-, no se adhiere plenamente a una fe entusiasta con relación a los restos de santa Juliana, sino que no deja de constatar que se trata de la «común opinión ${ }^{68}$, tecnicismo jurídico, sólo que en el presente contexto, no apunta tanto a la communis opinio doctorum, cuanto a una genérica creencia, cabría decir que popular. En cualquier caso, es testimonio de las cautelas que adoptaba Cartagena con respecto a lo que no dejaba de ser expresión de una devoción local y popular.

La causa aducida para la traslación es «non estar en logar decente» las reliquias ${ }^{69}$ : no sólo se refiere al estado en que éstas se encontraban, sino al lugar en que se hallaban

64 Se ha observado, a propósito de la doctrina de Gregorio Magno sobre las reliquias, que, conforme al uso de la Iglesia romana, el término reliquia designaba tanto resto corporal de un santo como objeto que había tenido contacto con el mismo, a diferencia del uso de la Iglesia griega que sólo incluía el primer significado (McCulloh 1976: 154-156). El Catholicon, como se ha visto, sancionaba el uso romano omnicomprensivo (Johannes Balbus 1460: f. 301 vo, s. v. reliquie).

65 Delehaye 1912: 344. El P. Flórez hacía referencia por una parte a la cabeza de santa Juliana, depositada en su tiempo en el Camarín de la Colegiata, y, por otra, al resto del cuerpo, junto al altar mayor (Flórez 1772: col. 70). Sobre el cuerpo dividido del santo venerado véase Angenendt 1994: 152-155. Y es que en la tradición occidental conviven dos tendencias en el culto de las reliquias, la que antepone la intangibilidad del cuerpo santo y la que avala su fragmentación (Swinarski 2000: 58-68).

66 Traslación: 366. De hecho, se trataba de un centro de peregrinación que atrajo desde sus orígenes la atención de condes, reyes y señores particulares (Flórez 1772: col.59).

67 Destaca el habitual componente maravilloso del origen de las reliquias Heinzelmann 1979: 56.

68 A la que apelaría para avalar un argumento clave en su discurso polémico De preeminentia pronunciado en Basilea (1434), la predicación de Santiago en España, como afirmaban oficios y lecturas litúrgicas. En ese punto, don Alonso remite al Corpus Iuris Civilis (Digesta 1.14.3). Cfr. Alonso de Cartagena. De preeminentia: f. 13 vo.

69 Traslación: 376. 
depositadas, que dificultaba la reunión de los fieles que se congregaban para venerarlas. En este punto, el prelado burgalés pone de manifiesto su sensibilidad estética, subordinada a los imperativos litúrgicos. ${ }^{70}$ Así, deja que su pluma se explaye en la ponderación de la calidad artística de la fábrica de la colegiata. ${ }^{71}$

Don Alonso narra cómo a continuación tomó la iniciativa de trasladar el cuerpo y reliquias de la santa a la capilla mayor, sita en la cabecera de la iglesia, «en logar decente, é honorable». ${ }^{72}$ Para ello se reunió con los beneficiados de la colegiata y los vecinos de la villa y notificó la decisión acordada respecto de las reliquias: «deliberamos que [...] trastadasemos [sic], é pasasemos el cuerpo, é qualesquier Reliquias que ello, ó de otro cualquier Sancto ó Sancta fallasemos estar en aquel logar, é los mudasemos á la Capilla mayor...». ${ }^{73}$

Al mencionar los fundamentos de la decisión adoptada, don Alonso sitúa en un primer plano su devoción por la Virgen, a quien estaba dedicada la capilla mayor. Dicha devoción constituye una suerte de seña de identidad del linaje y de hecho jugará un destacado papel en el tránsito final del prelado burgalés. ${ }^{74}$

\section{2.- La traslación}

Paradójicamente, el relato de la traslación propiamente dicha queda reducido a la mínima expresión. Se indica la fecha, de forma imprecisa dado que corresponde a la de la nueva festividad de santa Juliana que se establece con motivo de la traslación, seis de marzo. Del traslado de las reliquias se ofrece apenas un esquema de relato. Sólo se hace referencia a las circunstancias del acto: que se congregó una multitud considerable, tanto de la villa de Santillana como de sus comarcanas, y que se observó gran devoción y solemnidad. Y sólo esta última ofrece una indicación muy tangencial sobre el ceremonial seguido. El acto queda reducido en el relato de la Traslación al traslado y depósito de las reliquias ${ }^{75}$, como si se diera por supuesto el ritual que debía observarse en tales circunstancias. Y es que, ciertamente, la simple recolocación de las reliquias limitaba considerablemente el aparato ceremonial desplegado en tales ocasiones. No obstante, el hecho de que éstas se colocaran en lugar alto constituye un indicio de referencia

70 Dicha subordinación queda claramente de manifiesto en el locus veterotestamental aducido: «Ca escripto es por el Profeta David: Yo amé la fermosura de tu Casa». (Ibídem: 376). Cfr. Psalmi, 25, 8: "Domine, dilexi decorem domus tuae». Es de notar cómo Cartagena traduce "decor» por "fermosura» mientras que utiliza dicho cultismo «decor» en la descripción de la fábrica de la colegiata.

71 «... la latitudine, é espaciosa anchura é fermosura é decor de la Eglesia.... (Traslación: 376). Dicha sensibilidad decidiría la difusión del gótico germánico en Castilla a mediados del siglo Xv: durante su misión diplomática en Basilea, don Alonso quedó impresionado de las torres y flechas de las catedrales de Basilea y acaso Friburgo y Estrasburgo y decidió construir unas similares en su Burgos natal (García Cuetos 2006: 99-100).

72 Traslación: 377.

73 Ibídem: 376.

74 Para la devoción mariana de los Santa María véase Fernández Gallardo 2002: 33 y 272.

75 «... é passamos todas las reliquias ende falladas, é posimoslas en un lugar alto honorable é decente...» (Traslación: 377). a un componente ritual habitual: la «elevación». Se ha atribuido el carácter de «canonización» que presentaba este rito. ${ }^{76}$ No podía serle ajeno a don Alonso el significado de la elevación cuando decidió que las reliquias halladas en la colegiata se depositasen en «lugar alto honorable». Quizá se practicara este ritual en el curso de las ceremonias de traslación.

\section{V.- DISPOSICIONES LITÚRGICAS}

Tras el brevísimo relato de la traslación, don Alonso incluye la adopción de dos disposiciones de carácter litúrgico, que se presentan separadas por el hilo narrativo de las actuaciones del prelado burgalés. En primer lugar, establece éste que haya dos invocaciones, una de la Virgen y otra de santa Juliana. La cláusula absoluta con que inicia la referencia a la partida hacia Burgos, tras la inclusión de esta disposición ${ }^{77}$, abona la suposición de que se adoptara en el curso de las ceremonias de la traslación. La segunda disposición se refiere al calendario litúrgico, al traslado de la festividad de santa Juliana para hacerla coincidir con el día de la traslación: seis de marzo. Dicho cambio fue acordado en sesión capitular. Don Alonso revela aguda conciencia de la sensibilidad corporativa del cabildo catedralicio al justificar la notificación de las actuaciones llevadas a cabo en la Colegiata de Santillana: se trata de un imperativo del prelado. De ahí que en la invocación de los fundamentos de autoridad en que se sustenta la disposición del cambio de la festividad de santa Juliana se haga referencia tanto a la episcopal como al consentimiento del cabildo. ${ }^{78}$

La segunda disposición afecta al calendario litúrgico y constituye un reajuste para hacer coincidir la festividad de santa Juliana con el día de la traslación de sus reliquias. Se justifica tal medida por la necesidad de evitar la proliferación de festividades religiosas. La iniciativa es del propio obispo ${ }^{79}$, aun cuando cuente con la aprobación del cabildo. Dicha medida es coherente con la tendencia observada en el sínodo provincial de 1443, que abogaba por la reducción del número de fiestas en la diócesis burgalesa. ${ }^{80}$

Finalmente, se establece el ritual que se deberá seguir en la celebración de dicha festividad, que se habría de mantener como hasta entonces, salvo la mención de la segunda traslación.

\footnotetext{
76 Heinzelmann 1979: 80. Asimismo, en estrecha relación con esta visualización de la dignidad de las reliquias hay que situar el desarrollo del altar de reliquias (Snoek 1995: 209-213).

77 «E esto assi fecho, nos venimos á la Cibdad de Burgos...» (Traslación: 377-378).

78 «... é notificamoslo todo al Dean é Cabildo de nuestra Eglesia con quien las tales cosas, é otras qualesquier de alguna reputación se deben comunicar...» (Ibídem: 378). Para las relaciones, no exentas de tensiones, entre don Alonso y el cabildo burgalés véase Fernández Gallardo 2002: 264-265.

79 «... é con consejo, é consentimiento dellos deliberamos que la otra fiesta de la Translacion de Sancta Juliana fuesse pasada, é mudada al tiempo en que esta segunda translación se fizo, é amas translaciones se juntasen, é celebrasen en uno...» (Traslacion: 378).

80 Análisis de dicho sínodo en Fernández Gallardo 2002: 256-264 (para la cuestión de las festividades, 260-261).
} 


\section{VI.- OTRAS DISPOSICIONES}

La actividad normativa surgida con ocasión de la traslación de las reliquias de santa Juliana no se limitó a cuestiones meramente litúrgicas. Para promover la nueva festividad, teniendo en cuenta que dichas reliquias atraían una considerable corriente de peregrinos, el prelado burgalés concedió indulgencia a quienes acudieran a su celebración y estuviesen presentes en la celebración de vísperas, completas, maitines y, al día siguiente, prima, tercia, misa o sexta, nona, vísperas y completas. Se trata del tipo de indulgencia episcopal, que por la duración, cuarenta días, los "quadraginta dies criminalium», corresponde a lo establecido para los pecados mortales. ${ }^{81}$ Es de notar que no se establece como requisito para la obtención de la indulgencia donación alguna de limosna. Se exige, eso sí, estar «en estado de gracia» ${ }^{82}$ para el otorgamiento de la indulgencia. El tenor literal de esta sección de la Traslación recoge las fórmulas habituales en los documentos de concesión de indulgencias. Así, la referencia a los fundamentos en que se sustenta la autoridad episcopal para el acto de concesión reproduce a la letra la cláusula dispositiva corriente. ${ }^{83}$

La indulgencia concedida por Cartagena no tiene otra finalidad que incentivar la afluencia de fieles al santuario cuyo culto se quería impulsar a raíz de la remoción de las reliquias de santa Juliana. Se trata de una medida ordinaria adoptada en el uso de sus atribuciones prelaticias y que revela el alineamiento de don Alonso con la ortodoxia católica en relación con las indulgencias, precisamente en vísperas de que recibiesen en Castilla sólida contestación teológica por parte de uno de los más preclaros docentes de Salamanca, Pedro de Osma. ${ }^{84}$

En segundo lugar, don Alonso establece unas disposiciones relativas a la decoración y a la organización del espacio de la iglesia donde se albergarán las reliquias trasladadas. Para recuerdo de la primitiva ubicación de las reliquias, dispuso la erección de un pedestal de piedra del tamaño de una sepultura sobre el que se colocaría una imagen esculpida de la Virgen. ${ }^{85}$ Llama la atención la escasez de indicaciones relativas a dicha imagen: sólo su naturaleza escultórica, que esté fija, esto es, que no se pueda trasladar a otro lugar de la iglesia, y el tema, enunciado con extrema generalidad, simplemente "una Sancta Virgen». No se da instrucción alguna sobre el material. Es de notar que, en cambio, del

\section{Paulus 2000: 56-62.}

82 Traslación: 379.

83 «... Nos confiando en la misericordia de Dios todo poderoso é por actoridad de los Bienaventurados San Pedro é San Paulo sus Apostolos, damos é otorgamos a cada una de las personas, que estando en estado de gracia venieren [...] cada quarenta dias de perdon en remission de sus pecados...» (ibídem: 379). Cfr.: "Quocienscumque, quandocumque et ubicumque premissa uel aliquid premissorum deuote fecerint, de omnipotentis Dei misericordia et beatorum Petri et Pauli apostolorum eius auctoriatet confisi, singuli nostrum XL.a dies indulgenciarum de iniunctis eis penitentiis misericorditer in Domino relaxamus». (ápud García Lagarreta 1989: 332).

84 Analizada en su contexto social, político y religioso por lannuzzi 2007.

85 «E porque es raconable que aquel logar donde primero estaban las dichas Reliquias sea tenido siempre en reverencia, mandamos que sea puesta en él una piedra fermosa tan luenga, é ancha como se suele poner en una Sepultora, é en ella esté esculta, é fixa Imagen de una Sancta Virgen..» (Traslación: 379). pedestal se indica que la piedra ha de ser «hermosa». ${ }^{86} \mathrm{El}$ contexto, la referencia a la semejanza del pedestal con un sepulcro vendría a sugerir una estatua funeraria.

El obispo de Burgos no está encargando una imagen concreta que representara a la santa cuyas reliquias se custodiaban en la Colegiata. Estaba sugiriendo una representación de los atributos genéricos de una santa virgen -no es probable que se estuviera refiriendo a uno cualquiera de los motivos iconográficos de la Virgen María, pues se destaca la subordinación a la ubicación de las reliquias-. Don Alonso no parece manifestar especial interés por la forma específica de la imagen: ni siquiera especifica el tamaño. Extraña que quien mostrara gran sensibilidad ante las formas arquitectónicas, exhiba cierta indiferencia hacia las propiedades formales de la escultura. Si es que tan lacónicas instrucciones revelan alguna renuencia al uso de las imágenes religiosas, cabría suponer que la disposición relativa a la colocación de la imagen es una concesión a las demandas de la feligresía, de la sensibilidad popular. $Y$ es que no se oculta lo paradójico de que se engalane el emplazamiento primitivo de las reliquias y no se establezca nada para el nuevo. ¿Acaso Cartagena desviaba la demanda popular de una imagen a un lugar de culto menor? En cualquier caso, se transparenta escasa sensibilidad hacia la función religiosa de la imagen, cuando no una intención de situar hábilmente ésta en un lugar secundario con relación al culto de las reliquias.

La justificación de las disposiciones relativas a la decoración de la capilla donde estaban originalmente las reliquias no pone de manifiesto la función específica que se le asigna a la imagen: simplemente dichas disposiciones tienen como objetivo que «aquel logar [...] sea tenido siempre en reverencia». ${ }^{87}$ La imagen se subordina a que el espacio posea el decoro que requiere el recuerdo de la antigua ubicación de las reliquias. No tiene, por tanto, ninguna función asociada al culto, pues donde se alzaba no había nada que venerar. Tampoco se asocia a la promoción de la devoción religiosa, salvo que contribuye a recordar que se halla en un espacio que posee cierto carácter numinoso.

Así, pues, las indicaciones sobre la imagen de la virgen revelan precisamente por su parquedad una actitud distante por parte de Cartagena con relación a los usos de la imagen religiosa. Dicha actitud adquiere especial importancia si se sitúa en el contexto del debate que acerca de la imagen religiosa se desarrollaba entonces, el cual se vio condicionado por las específicas circunstancias hispanas de la polémica antijudía. Y en este punto hay que tener en cuenta la importante contribución del padre de don Alonso a dicho debate. En efecto, Pablo de Santa María, el patriarca del preclaro linaje converso, dedicó un apartado de su Scrutinium Scripturarum, una de las obras más notables de la controversia cristiano-judía, terminada en 1432, a rebatir la imputación de idolatría que desde la perspectiva judía se hacía a la veneración de las imágenes religiosas, en que mantiene una posición que se ha calificado de compromiso, minimizando el valor de la adoración que se debe a una representación de la divinidad y no concediéndole

86 No hay que perder de vista que la fascinación por los materiales preciosos es una de las características de la estética medieval (Barasch 2012: 85).

87 Traslación: 379. 
otro valor que el de mediadora. ${ }^{88}$ Don Alonso tenía que estar al tanto de las ideas de su padre al respecto. Las responsabilidades prelaticias de ambos hubieron de ser un poderoso condicionante en la valoración del carácter devoto de la imagen religiosa, en la medida en que tenían que ser condescendientes con las manifestaciones de la religiosidad popular que podían integrarse en la ortodoxia católica.

La posición distante de Alonso de Cartagena adquiere pleno sentido contemplada en el marco del debate mencionado, en el que desde sólidos presupuestos teológicos y escriturarios se alzaban voces contrarias a los usos de la imagen religiosa, como es el caso del Tostado. No hay necesidad de apelar a su condición de converso y a una herencia de una sensibilidad judía adversa al uso de la imagen religiosa -habría entonces que postular la insinceridad de su padre al disertar al respecto en el Scrutinium- como clave explicativa de su actitud distante, lo que no obsta el que en los círculos conversos hallaran acogida los planteamientos contrarios a las imágenes devotas. La formación de Alonso de Cartagena, salvo la posible iniciación a las primeras letras hebreas, fue esencialmente cristiana, dentro del paradigma escolástico. ${ }^{89}$ Desde tales coordenadas hay que valorar tal actitud. Ahora bien, tampoco hay que perder de vista que era reciente la primera gran acometida contra los conversos y la primera iniciativa de institucionalizar su marginación social, la Sentencia-Estatuto de Pero Sarmiento (1449), frente a la que don Alonso alzó su formidable erudición jurídica y teológica para denunciar lo aberrante del empeño discriminador. La sospecha indiscriminada que se pretendía extender sobre toda la colectividad conversa hubo de hacer a muchos de sus componentes muy sensibles a aquellos signos de la práctica religiosa que podía ofrecer un flanco débil a la denuncia de criptojudaísmo: los usos de la imagen eran uno de ellos. Así, en el gesto condescendiente con que se dispone la colocación de la imagen de una virgen tal vez haya que identificar la huella de la presión de un ambiente de sospecha ante cualquier disensión del sentir mayoritario cristiano-viejo. Y es que pocos años más tarde de la redacción de la Traslación el franciscano Alonso de Espina escribiría una de las obras más agresivas de la polémica cristiano-judía, el Fortalitium fidei, que contiene la más elaborada teoría de la imagen religiosa en la España del Cuatrocientos y formula con rigurosa argumentación teológica lo que se ha denominado bizantinización de la imagen, esto es, la transferencia de un valor sacramental que se le añade al de mera representación. ${ }^{90}$

\section{VII.- CONCLUSIONES}

La aportación de Alonso de Cartagena al género narrativo de la traslación de reliquias se revela especialmente notable en un contexto hispánico caracterizado por su limitado cultivo y por el carácter nacional de sus testimonios más destacados. Referida a una santa cuyo culto tenía un acusado

88 Véase el acabado análisis de las ideas de don Pablo al respecto que ofrece Pereda 2007: 88-89.

89 Fernández Gallardo 2002: 44-48. Ponderada valoración de los condicionamientos de la herencia -o psicología- conversa en Lawrance 1993.

90 Análisis de las ideas de Espina sobre la imagen religiosa en Pereda 2007: 109-143. Para su posición en la polémica anti-conversa véase Netanyahu 1999: 739-768 y sobre todo Vidal Doval 2013. carácter local, la obra de don Alonso tiene muy presente la naturaleza de la feligresía congregada en los actos litúrgicos de la traslación de los restos de santa Juliana: de ahí su perspectiva eminentemente catequética y, por tanto, el uso del castellano, frente a la solemnidad del latín de la mayor parte de los testimonios hispanos de este género narrativo, lo que otorga especial singularidad a esta muestra de la literatura hagiográfica castellana.

Y en ello reside precisamente el interés de la Traslación. Su autor expone los fundamentos del culto de las reliquias conforme a la doctrina tomista con una claridad compatible con el rigor de la exposición teológica, donde se pone de manifiesto el genio didáctico del quehacer intelectual del obispo de Burgos. Entre las disposiciones de orden litúrgico que contiene, presentan especial interés las relativas a la imagen de santa Juliana, que ponen de manifiesto una actitud distante con relación al uso de las imágenes religiosas, especialmente significativa en el momento del debate teológico sobre esta cuestión. El análisis de la Traslación permite completar y matizar el perfil intelectual de su autor, una sensibilidad religiosa en la que se advierte el esfuerzo por hacer compatibles unas profundas convicciones, sustentadas en sólida base teológica, y la necesidad, impuesta por su responsabilidad prelaticia, de hacer concesiones a determinadas formas de piedad popular, si no mayoritaria.

\section{BiBLIOGRAFÍA CITADA}

Agustín de Hipona. 1865. "De vera religione», en J. P. Migne (ed.), Patrologia Latina, t. XXXIV: cols. 121-172. París: In Via d’Amboise.

Álvarez Turienzo, S. 1987. "La Edad Media», en V. Camps (ed.), Historia de la ética. 1. De los griegos al Renacimiento: 345-489. Barcelona: Crítica.

Angenendt, A. 1994. Heilige und Reliquien. Die Geschichte ihres Kultes vom frühen Christentum bis zur Gegenwart. Múnich: Verlag C. H. Beck.

Angenendt, A. 2010. "Relics and their Veneration», en M. Bagnoli et alii (eds.), Treasures of heaven: saints, relics and devotion in Medieval Europe: 19-28. Baltimore: The Walters Art Museum.

Aquino, T. de. Summa Theologiae. http://www.corpusthomisticum. org/iopera.html\#OM

Barasch, M. 2012. Teorías del arte. De Platón a Winckelmann (1985). Madrid: Alianza Editorial.

Brown, P. 1981. The Cult of the Saints. Its Rise and Function in Latin Christianity. Chicago: The University of Chicago Press.

Bustos Tovar, J. J. de. 1974. Contribución al estudio del cultismo léxico medieval. Madrid: RAE.

Cartagena, A. de. De preeminentia: ff. 8-25 ro. BNE, ms. 9262.

Delehaye, H. 1912. Les origines du culte des martyrs. Bruselas: Bureaux de la Société des Bollandistes.

Deyermond, A. 1990. "Lost Hagiography in Medieval Spanish: A Tentative Catalogue», en J. E. Comolly et alii (eds.), Saints and their Authors: Studies in Medieval Hispanic Hagiography in Honor of John K. Walsh: 139-148. Madison: The Hispanic Seminary of Medieval Studies.

Escagedo Salmón, M. 1927. Colección Diplomática. Privilegios, escrituras y bulas en pergamino de la Insigne y Real Iglesia Colegial de Santillana, t. II. Santoña: Tipografía Dialco Mnemaen.

Fernández Gallardo, L. 2002. Alonso de Cartagena (1385-1456). Una biografía política en la Castilla del siglo xv. Valladolid: Junta de Castilla y León.

Fita, F. 1885. "Traslación e invención del cuerpo de San Ildefonso. Reseña histórica por Gil de Zamora». Boletín de la Real Academia de la Historia 6: 60-71. 
Flórez, E. 1772. España Sagrada, t. XXVII. Madrid: Antonio de Sancha. Flórez, E. 1789. España Sagrada, t. XXXVII. Madrid: Oficina de Blas Román.

García Cuetos, M. P. 2006. «De maestros, bóvedas, pórticos y torres. Tradición e innovación en el tardo gótico de la fábrica catedralicia ovetense». De Arte 5: 87-106.

García Lagarreta, S. 1989. "Cartas de indulgencia». Historia. Instituciones. Documentos 16: 319-355.

Harnack, A. von. 1890. Lehrbuch der Dogmengeschichte, t. III. Friburgo: Akademische Verlagsbuchhandlung von J. C. R. Mohr.

Heinzelmann, M. 1979. "Translationsberichte und andere Quelle der Reliquenkultes», en L. Génicot (ed.), Typologie des Sources du Moyen Âge Occidental, fasc. 33, Turnhout: Brepols.

Historia Silense. 1959. ed. Fr. J. Pérez de Urbel, A. Ruiz Zorrilla. Madrid: CSIC.

Iannuzzi, I. 2007. "La condena a Pedro de Osma: 'ensayo general' de control ideológico inquisitorial». Investigaciones históricas 27: 11-46.

Jacobus a Voragine. 1890. Legenda aurea, ed. Th. Graesse. Bratislava, Apud Guilelmum Koebner.

Johannes Balbus Januensis. 1460. Catholicon. Mainz: Gutenberg?.

Kohler, Ch. 1897. "Translation de reliques de Jérusalem à Oviedo (VII IX siècle)». Revue de l'Orient latin, V: 1-21.

Kühne, H. 2000. Ostensio Reliquiarum. Untersuchungen über Entstehung, Ausbreitung, Gestalt und Funktion der Heiltumsweisungen in römisch-deutschen Regnum. Berlín-Nueva York: Walter de Gruyter.

Lawrance, J. 1993. "Alfonso de Cartagena y los conversos», en A Deyermond et alii (eds.), Actas del primer congreso anglo-hispano, t. II (Literatura): 103-120. Madrid: Castalia.

Lawrance, J. 2000. «De actibus Alfonsi de Cartagena: Biography and the Craft of Dying in Fifteenth-Century Castile», en D. Hook (ed.), Text \& Manuscript in Medieval Spain. Papers from the King's College Colloquium: 121-184. Exeter-Londres, King's College.

Lorenzana, F. 1862. «/sidoriana», en J. P. Migne (ed.), Patrologia Latina, t. LXXXI: cols. 9-568. París: In Via d’Amboise.
McCulloh, J. M. 1976. "The Cult of Relics in the Letters and 'Dialogues' of Pope Gregory the Great: A Lexicographical Study». Traditio XXXII: 145-184.

Morrás, M. 1991. "Repertorio de obras, manuscritos y documentos de Alfonso de Cartagena». Boletín Bibliográfico de la Asociación Hispánica de Literatura Medieval 5, no 20: 213-248.

Morrás, M. 2003. "Alfonso de Cartagena», en C. Alvar; J. M. Lucía Megías (eds.), Diccionario Filológico de Literatura Medieval Española. Textos y documentos: 93-127.

Netanyahu, B. 1999. Los orígenes de la Inquisición en la España del siglo XV. Barcelona: Crítica.

Nuevo Diccionario Histórico del Español. <http://web.frl.es/CNDHE/ view/inicioExterno.view>.

Paulus, N. 2000. Geschichte des Ablasses im Mittelalter. Vom Ursprunge bis zur Mitte des 14. Jahrhunderts (1922), t. II. Darmstadt: Wissenschaftliche Buchgesellschaft.

Pereda, F. 2007. Las imágenes de la discordia. Política y poética de la imagen sagrada en la España del 400. Madrid: Marcial Pons Historia.

Pulgar, F. de. 1985. Claros varones de Castilla, ed. R. B. Tate. Madrid: Taurus.

Ratzinger, J. (Benedicto XVI). 2007. Jesús de Nazaret. Madrid: La Esfera de los Libros.

Serrano, L. 1942. Los conversos don Pablo de Santa María y don Alfonso de Cartagena, obispos de Burgos, gobernantes, diplomáticos y escritores. Madrid: CSIC.

Snoek, G. J. C. 1995. Medieval Piety from Relics to Eucharist. Leiden: Brill. Swinarski, U. 2000. «Der ganze und der zerteilte Körper. Zu zwei gegensätzlichen Vorstellungen im mittelalterlichen Reliquienkult». en D. R. Rauber, K. Herbers (eds.), Hagiographie im Kontext: 58-68. Stuttgart: Franz Steiner Verlag.

Valla, L. 1526. In Novum Testamentum annotationes. Basilea: (sin indicación de imprenta).

Vidal Doval, R. 2013. Misera Hispania: Jews and Conversos in Alonso de Espina's Fortalitium fidei. Oxford: The Society for the Study of Medieval Languages and Literature. 